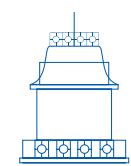

ARTÍCULOS

DE INVESTIGACIÓN

\title{
The role of reason in the establishment of practical goals. A dialogue with some interpretations of Aristotle ${ }^{*}$
}

\author{
Laura Liliana Gómez Espíndola \\ Universidad del Valle, Cali, Colombia \\ E-mail: laura.gomez@correounivalle.edu.co
}

Recibido: 25 de febrero de 2021 | Aceptado: 22 de abril de 2021

https://doi.org/10.17533/udea.ef.345410

\begin{abstract}
There is a current debate about the interpretation of the Aristotelian theory of action concerning the role of reason in the establishment of practical ends, given that in some passages Aristotle assigns to character the role of establishing ends, and in others he gives reason the role of government in the soul. How can these two groups of textual evidence be reconciled? In this article I will argue that these two types of evidence explain two different psychological phenomena. For this purpose, I will discuss the main and most recent interpretations in this debate (intellectualism, anti-intellectualism and indirect intellectualism), showing how, although character establishes our habitual representations, desires and actions, reason can question and oppose them, as we can see in the processes of character change.
\end{abstract}

Key words: Aristotle, practical reason, character, desire, phantasia, intellectualism

* Este texto se ha escrito en el marco de la investigación Libertad de acción y transformación moral, un estudio desde la psicología moral de Aristóteles, financiada por la Universidad del Valle. Ajustes finales se realizaron en el marco de la comisión de año sabático concedido por la misma universidad. Un borrador previo se presentó en el $I V$ encuentro de investigación en historia de la filosofía UNAM-Univalle. Agradezco a todos los participantes de este evento por sus valiosas observaciones, particularmente a Juan Pablo Bermúdez, François Gagin, Edgar González, Teresa Rodríguez, José Tovar, Ricardo Salles y Mauricio Zuluaga. Así mismo, agradezco a Leonardo Ramos-Umaña, Patricia Simonson y Leonardo Tello por sus observaciones a mis borradores previos. Se usará las siguientes abreviaturas: Cat = Categoriae; de An. = De anima; EE = Ethica Eudemia; EN = Ethica Nicomachea; ma $=$ De Motu Animalium; Metaph. = Metaphysica; Pol. $=$ Poltica. .

\section{Cómo citar este artículo}

Gómez Espíndola, L. L. (2022). The role of reason in the establishment of practical goals. A dialogue with some interpretations of Aristotle. Estudios de Filosofía, 65, 113-131. https://doi.org/10.17533/ udea.ef.345410

\section{OPEN ACCESS}

Estud.filos n. ${ }^{0}$ 65. Enero-junio de 2022 | pp. 113-131 | Universidad de Antioquia | ISSN 0121-3628 | ISSN-e 2256-358X 


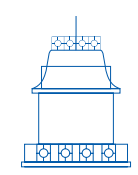

ARTÍCULOS

DE INVESTIGACIÓN

\section{El rol de la razón en el establecimiento de los fines prácticos. Un diálogo con algunas interpretaciones de Aristóteles}

Resumen: Se ha desarrollado en la actualidad un debate acerca del rol de la razón en el establecimiento de los fines prácticos en la teoría aristotélica de la acción, dado que en algunos pasajes Aristóteles reserva al carácter el rol de establecer los fines y en otros confiere a la razón el rol de gobierno en el alma. ¿Cómo se pueden conciliar estos dos grupos de evidencia textual? En este artículo defenderé que estos dos grupos de evidencia explican dos fenómenos psicológicos diferentes. Para llegar a esta propuesta dialogaré con las interpretaciones principales y más recientes en este debate (intelectualismo, anti-intelectualismo e intelectualismo indirecto), mostrando cómo, si bien el carácter establece nuestras representaciones, deseos y acciones habituales, la razón puede cuestionar y oponerse a ellos, como se ve en los procesos de cambio de carácter.

Palabras clave: Aristóteles, razón práctica, carácter, deseo, phantasia, intelectualismo

Laura Liliana Gómez Espíndola realizó sus estudios en filosofía en la Universidad Nacional de Colombia. Posteriormente realizó allí su Doctorado en Filosofía desarrollando una investigación sobre las relaciones entre el destino y la responsabilidad en el estoicismo. Desde el 2010 es profesora del Departamento de Filosofía de la Universidad del Valle y directora e investigadora del Grupo Ágora: diálogo entre antiguos y modernos. Su campo de investigación son las teorías clásicas de la formación moral, el determinismo y la responsabilidad.

ORCID: 0000-0003-2332-8730 
What specific role can reason play in producing our actions? There have been two kinds of answers to this question. The first view has been labelled intellectualism. According to this interpretation, practical reason has a central role in establishing our goals. The second position has been labelled anti-intellectualism. According to this second view, only character can establish the goals of our actions. Bermúdez has recently assessed both groups of interpretations and has proposed an attractive solution for avoiding the problems he finds in both of them. He has called his proposal indirect intellectualism, a thesis based upon the idea that reason can establish the goals of our actions (against anti-intellectualism), but only indirectly through the care of character (against intellectualism).

In this paper, I will dialogue with the most important and recent discussions of this question. First, I will give a quick overview of the intellectualist position. Second, I will briefly introduce Moss's critique and her alternative anti-intellectualist interpretation. I will present three critiques of the anti-intellectualist view, in order to defend the following arguments: (i) reason and character can work together in establishing the content of the highest goal, the intermediate goals and the most particular decisions; (ii) our habitual phantasia of the good is not merely a non-rational cognition; and (iii) reason can furnish alternative non-habitual phantasiai of the good, that can produce non-habitual rational desires and non-habitual actions. And thirdly, on the basis of these arguments, I will present Bermúdez' indirect anti-intellectualism and my critique of this alternative interpretation. I will argue that care of character presupposes direct intellectualism, more precisely (iii). As a result of this analysis, in the final part of my article, I will defend an alternative position, to reconcile the two types of textual evidence that sometimes give character the role of establishing our desires, and sometimes confer the role of governing the soul on reason. I will argue that these two theses do not contradict each other; rather, they explain two different psychological phenomena.

\section{The intellectualist interpretation}

Broadly speaking, intellectualism is the position that assigns to reason the role of establishing the goals of our actions. Aristotle clearly states that reason, by way of deliberation, has the instrumental function of establishing the means required to achieve a determined goal. But intellectualists have pointed out two more roles that reason may play in order also to establish the goals of our actions. These two functions correspond to two different kinds of intellectualism.

Specification intellectualism (cf. Irwin, 1975; Mc Dowell, 1998; Wiggins, 1975) those who embrace this position begin by acknowledging that Aristotle bestows on character the role of establishing the goals of our actions. However, they consider that the goals established by our characters are rather general and abstract. The virtuous character of an agent establishes, for example, that he will pursue happiness and perform fine 
and virtuous actions. But it is the task of reason to specify in each precise situation what counts as attaining the goal. Thus, for example, a citizen's reason might say that what counts as a virtuous action in the particular moment of an external attack is to remain firm on the battlefield. Thus, reason can specify the intrinsic features of the goal to be pursued in these particular circumstances.

Coordination intellectualism (cf. Broadie, 1991; Price, 2011; Wiggins, 1975) this kind of intellectualism is based upon the coordinative role that reason can play in relation to the particular goals. Reason may evaluate each particular goal in order to determine whether or not it is consistent with more general goals of our life and other particular goals we have already embraced. Given this analysis, reason might accept, postpone or even reject the pursuit of each particular end. This function allows the agent to have a coherent and unified life. It has been understood that this rational activity focusses on goal-extrinsic details; it is not associated with determining the goal-intrinsic features.

\section{The anti-intellectualist interpretation}

Moss (2012) and Bermúdez (2017) have recently argued against the intellectualist interpretation. They maintain that there is a well-documented thesis of Aristotle that precludes this view: "The Division of Labor: Character, and not reason, sets the goal of human action. Reason must take the goals set by character as its starting points" (Bermúdez, 2017, p. 43).

Moss and Bermúdez consider that this is an essential feature of all human action. Only character is responsible for furnishing the goals of our actions. Reason has no role in establishing these goals. And this is so, they insist, because Aristotle argues that there is no syllogizing or logos about the end: it must be defined by character as

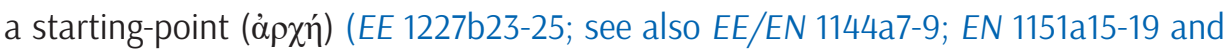
EN 1145a5-7).

In order to explain this interpretation, let us remember the essential structure of action formulated by Aristotle in De Anima and De Motu Animalium. He states that an agent is moved when something appears to him as good and, as a result, desire arises. So, the first mover of the animal is the object of desire, that which is represented by the agent as good. But, simultaneously, that appearance of good (i.e. the representation of an object as pursuable or avoidable) depends on the agent's character. This character, Moss and Bermúdez believe, is acquired through a non-rational process of habituation, which provides us with non-rational cognitions of things as avoidable or pursuable. It is the repetitive performance of certain kinds of actions which leads us to perform them more easily and, at the same time, to find them more pleasurable and therefore more pursuable. Reason, they believe, cannot do anything in order to make something appear more pleasurable and pursuable (this is the task of character alone). What reason does is to find the means to attain what appears pleasurable given our character. 
But this is not the only role Moss and Bermúdez concede to reason. They believe that intellectualists are right in granting reason the function of specifying the goals set by character and coordinating character's specific goals in order to achieve a coherent and unified life. Then why do Bermúdez and Moss not see themselves as intellectualists? They claim that according to their interpretation, these functions are secondary tasks that can be performed only when character has established the main features of the end. Our habitual dispositions are responsible for establishing the basis of our desires, the main ingredients for reason's subsequent operation.

\section{First critique of the anti-intellectualist interpretation}

Given the fact that intellectualists also consider that character establishes the main features of the end, and reason subsequently plays the roles of specification and coordination, it would seem that the difference between intellectualism and antiintellectualism is rather diffuse. What are the goals which are established only by character?

On the one hand, Moss speaks of them as a fundamental scheme of values that is not subject to rational evaluation and therefore cannot be altered by reason. She does not say much more about this fundamental scheme of values. ${ }^{1}$ When she explains the difference between her view and what we are calling specification intellectualism, she says that, although she recognizes the specificatory work of reason, there should be a line of distinction between the end established by character and the means established by reason. The ultimate end established by character cannot merely be happiness, she says, because this is shared by all human beings. This ultimate end should be something proper to each character. Thus, for the virtuous agent, the end would be the life of virtuous action. Moss claims: "deliberation cannot teach us that eudaimonia consists of the life of virtuous activity - only character can do that- but it can work out the whole substance of that general goal, showing at every point what counts as an achievement of it" (2012, pp. 197-198). Thus, in each specific situation it is reason that is in charge of determining what counts as a virtuous activity, but the end -the life of virtuous action- is something established only by character. ${ }^{2}$

But later, Moss also says that character gives us "more specific goal-appearances" such as to "eat temperately, or stand firm in battle" (2012, p. 223). Those more specific goals attributed previously to the action of deliberation are now attributed to the action of character. In the same line, Bermúdez claims that character-determined ends are not only 'happiness', 'doing well', or 'the fine and the noble', but more precise ends like the doctor's goal 'to heal' or the gymnast's goal 'to be in shape', and also 'wealth' 'pleasure', and all the 'deliberation starting points' (2017). Where does the work of character

1 We find the idea of a fundamental scheme of values prior to reasoning also in Grönroos (2015).

2 A similar line of argumentation is defended by Irwin (1975). 
end and that of reason begin? If we are going to defend the Division of Labor thesis, where exactly are we going to draw the dividing line? My own interpretation is that it is impossible to draw a dividing line, because character and reason can work together, from the establishment of the content of the most general goal to the specification of the most particular means.

(i) Aristotle claims that there can be reasoning about the highest good, i.e., about what eudaimonia means. (a) His own ethical works begin with a philosophical study of the content of this final end. Aristotle says that knowledge of the final end

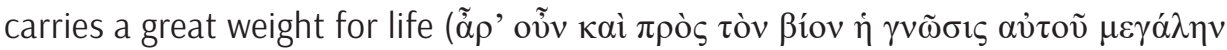

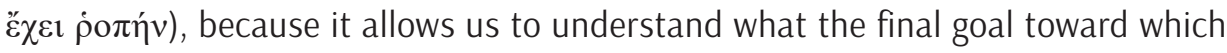
our lives should be directed is, and just as an archer who has a target to aim at can hit the mark more easily, we could achieve happiness more successfully if we had knowledge of what our highest good is (1094a22-26). ${ }^{3}$ (b) He also says that we could try to persuade people who have a mistaken idea of what happiness is through reasoning in order to correct their conception of happiness (EE 1216b 2530). (c) Aristotle uses the expression "he chooses this kind of life" throughout his analysis of the types of life that are possible examples of the happy life (EE 1215a 35; 4 EN 1095b 20-22; Pol. 1324a 29-32), explaining the kind of reasons people give for choosing the life they live, so this proairesis suggests an intervention of reasoning in the establishment of the highest good. ${ }^{5}$ (d) Aristotle refers to our conception of what constitutes a happy life as something that can fluctuate according to our circumstances (EN 1095a 24-26), so it is possible that our representation of the final end could be altered by reflection about experiences, and not be absolutely fixed by our habitual dispositions.

(ii) Aristotle claims that there could be deliberation also about more particular goals. He says:

3 To claim that Aristotle's investigation proposes only a theoretical knowledge of how to define happiness and not a practical knowledge of which end one should pursue is an illegitimate critique of my argumentation. In fact, Aristotle himself claims: "our present discussion does not aim, as our others do, at study; for the purpose of our examination is not to know what virtue is, but to become good, since otherwise our investigation would be of no benefit to us" (EN 1103b26-29).

4 After talking of a proairesis of life in this line, Aristotle analyses in EE I.5 the ways of living that are elegible (aiperóv). Although in this chapter he does not use the term proairesis, but hairesis, he is discussing the life different agents choose or reject over other possibilities based upon certain reasoning (1215b 17, 21, 35; 1216a15, 21).

5 The anonymous reviewer suggested to me that "proairesis of life" does not necessarily imply choosing ends, and not merely means, because it could be understood as "common parlance" for "deciding to follow a life of x". But even understood this way, the decision made by the agent here is not to perform a particular action as a means to achieve some goal, but to live choosing some kind of action, in the belief that this kind of action is what constitutes a happy life. Thus, "deciding to follow a life of $x$ " over "following a life of $y$ ", implies that the agent chooses one conception about what constitutes a happy life over another. This proairesis implies the ability to represent and rationally select between different options. Now it is important to notice that Aristotle is discussing here whether lo live a life of pleasure, virtue or study, the different forms which can define happiness, or the highest good. On this point, see Vigo's theory of ascendent deliberation and proairesis (Vigo, 2012). 
We wish for the end, but we decide on things that promote the end. We wish, for instance, to be healthy, but we decide to do things that will make us healthy; and we wish to be happy, and say so, but we could not appropriately say we decide to be happy, since in general the things we decide on would seem to be things that are up to us (EN 1111b 26-30; Irwin's translation).

Happiness is the highest end, and we can deliberate and decide about all the other things subordinated as means to promote happiness, and, according to the Aristotelian hierarchical structure of goals, that includes every intermediate goal (EN 1094a27-b8). On this point, I completely agree with Vigo's position, that even when it is true that the doctor does not deliberate about the end (to heal) but about the means (how to produce health) when he is attending his patient, this does not preclude the possibility that this very person could have deliberated at a previous moment in his life about whether he wanted to devote his life to healing people or to something else (teaching, singing, etcetera) (Vigo, 2001). The very same argument could be given in relation to what Bermúdez calls "all the starting points of deliberation": I want to be in shape, I want to earn money, etcetera. All of them could be articulated as intermediate goals in previous processes of deliberation.

With (i) and (ii), I do not want to deprive character of its well-documented role in serving both the highest and the intermediate goals. What I want to point out is that reason might also (and in certain particular circumstances) have something to say in order to establish, evaluate and modify those goals.

Aristotle claims that habitual dispositions have a role in establishing the most particular means. Decisions are, of course, the results of rational processes of deliberation. But in such cases, we cannot talk about a division of labor either. Reason is not solely responsible for establishing the means. Instead, habitual dispositions are co-responsible in choosing the appropriate means. Aristotle defines virtue as a

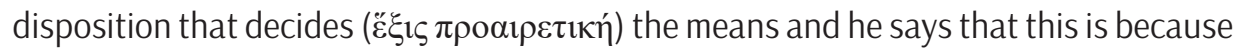

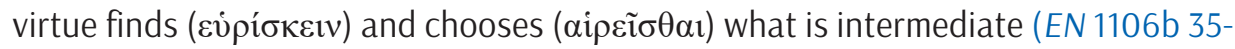
$1107 a$ 5). In the same way that habitual dispositions can define the representation of some particular goal as good, habitual dispositions help reason to provide the rational phantasia that some particular action is better in order to fulfill the goal. Thus, for example, if the agent has a cowardly character he will establish a deficient action as the correct one to perform, the rash will represent an excessive action as better, while the brave and virtuous agent will choose the mean.

The reason why habitual dispositions have this influence in decision-making is that in the practical sphere (vs. the productive sphere) what is chosen through a process of deliberation is not an instrumental means, in which case reason could carry out a merely instrumental calculation. In praxis the performance of the action is the very end pursued through performance (EN 1140b5-11). As a result, what is established through practical deliberation is what constitutes, in certain particular circumstances, 
a way to achieve the goal. Thus, if we have the goal of acting virtuously, generously, bravely, and so on, our habits may provide information about what counts as virtuous, generous, and brave under these circumstances and that is what we choose.

\section{Second critique of the anti-intellectualist interpretation}

Moss (2012) argues that each character furnishes its distinctive phantasia of what is good, which is what establishes the object of desire and therefore constitutes our desires. Let us call the phantasiai that correspond with our habitual dispositions habitual phantasiai. She argues that each habitual disposition is generated through a non-rational process of habituation in the performance of a certain kind of action which leads us to feel pleasure in its performance and thus to furnish this kind of phantasia as a non-rational cognition of the good. My second critique of Moss' proposal relies on the thesis that reason plays a role in configuring our habitual phantasiai. Children's moral education does not merely focus on the repetitive performance of certain movements but simultaneously on the attainment of the intellectual virtues related with action: $\varphi \rho o ́ v \eta \sigma \iota \varsigma, v o \tilde{\varsigma}, \sigma \delta ́ v \varepsilon \sigma \iota \varsigma, \gamma v \omega ́ \mu \eta$. We should not conceive the development of virtues of character and intellectual virtues as being completely independent of each other, just as we cannot conceive their future exercise in this way. Although habituation of the appetitive part of the soul is based upon the repetitive performance of a certain kind of action, moral education simultaneously implies the training of the critical faculties in such a way that the child becomes progressively able to discern what counts as virtuous and vicious. Aristotle says:

and since virtue has to do with being delighted correctly and loving and hating correctly, it is clear that there is nothing one should learn ( $\mu \alpha v \theta$ áveiv) and

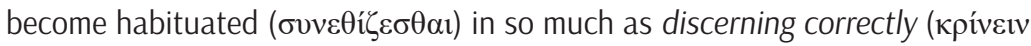
ò $\rho \tilde{\theta} \varsigma$ ) and delighting in virtuous characters and fine actions (Pol. 1340a14-19; Moss's translation). ${ }^{6}$

But the correct discernment of a just, brave or generous action presupposes the skill to perceive the just and the unjust, the brave and the cowardly, the generous and the

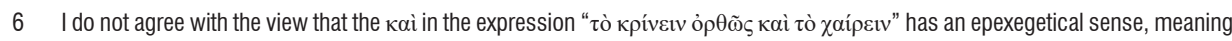
that to discern correctly consists in being correctly delighted. First, because the passage refers to two parts of education:

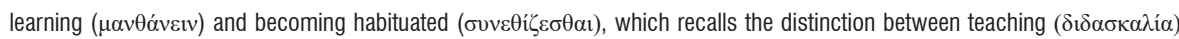
and habituation $(\check{\varepsilon} \theta \circ)$, the two different paths to acquiring the intellectual and ethical virtues, and in this passage the paths to learning to discern correctly and be correctly delighted. Second, because Aristotle does not consider that to discern correctly consists in being correctly delighted. Instead, he insists that "in everything we must guard overall against pleasure and pain,

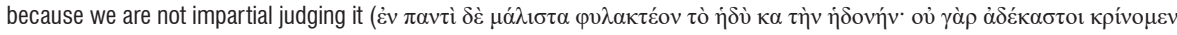

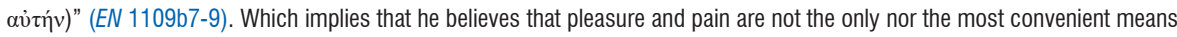

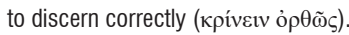


ungenerous. An animal and a very young child are not able to perceive these qualities and the reason is that they lack reason ( $\lambda$ ó $\left.\sigma^{\circ}\right)$ ). They are only able to perceive and to communicate pleasure and pain, but rational animals can perceive and communicate the good and the bad, the just and the unjust (Pol. 1253a9-18). When children progressively acquire logos, we could properly say that we are giving them the instruction to perform a generous, brave or just action and that they are understanding the instruction. We are not training them, for example, to stretch their arm and drop an object in the hands of another person; we are teaching them that in contexts like the one in which he or she is involved, a certain kind of behavior constitutes a generous action, and that this behavior is desirable. All this involves the acquisition of logos. If through education we teach children to delight in virtuous characters and actions, it is partly because through education we give them the knowledge that allows them to discern correctly what is virtuous and what is vicious. ${ }^{7}$ And in this way, our habitual phantasiai are not merely non-rational cognitions, just as our habitual dispositions are not merely a nonrational construction.

Secondly, through education we do not merely instill in children certain tendencies to perform certain kinds of actions. We teach them something that is no less important: that they have to hear and be obedient to reason. In the beginning they have to be obedient to the instructions of their parents and educators, but progressively they have to listen to their own reason. Aristotle many times characterizes the virtuous agent as one who is able to listen to reason and, furthermore, as someone who follows reason's instructions. Due to this capacity to hear and obey reason, at the beginning of moral habituation, our parents and educators will instill into our souls the notions and habits that will furnish our future habitual phantasiai of what is good. But later, our own reason can play the role of evaluating habits and new experiences and establishing alternative phantasiai of the good, as I will argue in the next critique.

\section{Third critique of the anti-intellectualist interpretation}

The next critique that I want to posit against anti-intellectualism is based upon the idea that although our character furnishes the corresponding habitual phantasiai of what is good, reason can generate phantasiai of the good opposed to our habitual

7 I think McDowell's (1998) and Grönroos's (2015) interpretation of habituation is very similar to what I am proposing here. In contrast, Irwin (1975) points out that habituation produces the promising raw material that later requires practical wisdom in order to become virtue. I am suggesting here, in contrast, that the intervention of reasoning in moral education does not follow directly on the acquisition of the promising raw material through habituation; rather, a progressive reasoning is also necessary for the process of habituation itself. Aristotle frequently says that children must listen and follow the instructions of their parents and educators, and this is only possible when they are able to understand these instructions, i.e. it is only possible when they have acquired logos. Logos enables children to progressively perceive, understand and communicate better the good and the bad, the just and unjust, and so on. 
phantasiai. Just as the discovery of a particular case, in the theoretical realm, could lead us to reevaluate and reject a generalization based on our previous perceptions (e.g. seeing a black swan can force us to deny the belief that all swans are white), in the same way, in the practical sphere, the experience of a particular shocking situation might lead us to question, reevaluate and even reject our ethical generalizations of what is good. For example, someone could wonder whether the life of moneymaking or professional success is the happy one, when he realizes that his family is being destroyed by his lack of attention. Someone else might wonder whether the life of pleasure is the happy one, when he discovers he has acquired a terrible disease because of his way of living. Reflection on these new experiences could generate rational phantasiai according to which specific way of living, contrary to or different from the one he has been following, is better; thus, it could generate the belief that this non-habitual behavior is better, which in turn could produce a rational desire

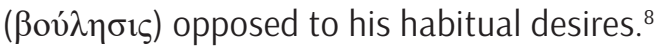

Aristotle's psychology of action opens up this possibility. He says that opinion may be opposed to phantasia, given the fact that they are not in the same part of the soul. Thus, sometimes we might have the phantasia that the sun is two feet wide, but simultaneously we might believe that it is much wider. And the same thing happens in relation to our practical phantasiai of the good. Sometimes, we have the phantasia that something is good, because it is pleasant, but simultaneously we may believe it is not good (EE 1235b 26-30). Aristotle saw this conflict between opinion and sensitive phantasia as the basis for explaining the conflict between rational desires and appetites.

Since desires run counter to one another, which happens when reason ( $\lambda$ ó os $_{\text {) }}$ and appetites ( $\left.\dot{\varepsilon} \pi \imath v \mu i \alpha_{1}\right)$ are contrary and is possible only in beings with a sense of time (for while thought (voũs) bids us hold back because of what is future, appetite ( $\left.\dot{\varepsilon} \pi \imath v \mu \boldsymbol{i}^{\alpha} \alpha\right)$ is influenced by what is just at hand: a pleasant object which is just at hand presents itself as both pleasant and good, without condition in either case, because of want of foresight into what is farther away in time) (de An. 433b 5-10; See also EE 1240b28-14 and EN 1166a1-b30).

In this conflict an agent, through sense perception, recognizes an object as pleasant and therefore immediately feels the appetite $\left(\dot{\varepsilon} \pi \imath v \mu i^{\alpha}\right)$ to obtain it. But thought

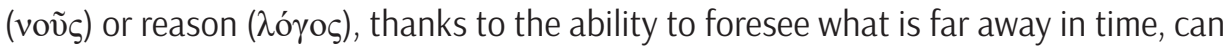
understand that to give in to this appetite is not the most convenient course of action.

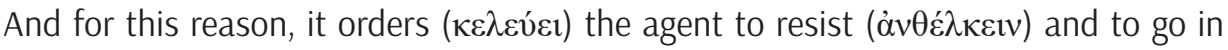

8 Grönroos (2015) claims that in order to show that the intellect can produce wishes, "the intellectualist case requires that an agent can form a conception of goodness through reasoning without appeal to values already desired by the agent" (p. 66). I think intellectualists cannot do such a thing, and, besides, that Aristotle's strategy to rationally alter our conception of the end is based on the previous experiences of the agent (cf. EE 1216b 25-30). But I do think that a new element should be incorporated in order to alter our conceptions. That is why I appeal to the new, contradictory and shocking experiences. 


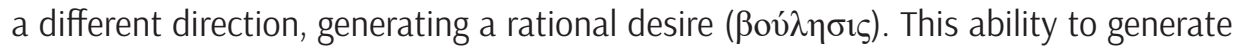
opinions contrary to phantasiai could be the psychological basis for granting reason the role of generating opinions contrary to our habitual phantasiai and, in this way, wishes contrary to our habits. This role was envisaged by Aristotle in his Politics:

There are three things which make men good and excellent; these are nature habit and reason. [...] Animals lead for the most part a life of nature, although in lesser particulars some are influenced by habit as well. Man has reason, in addition, and man only. For this reason nature, habit, reason must be in harmony with one another; for they do not always agree; men do many things against habit and nature, if it persuades them that there is a better way of acting ( $\dot{\varepsilon} \alpha \mathrm{v}$

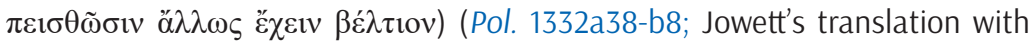
slight modifications).

The reflection about new experiences will not move us to action unless reason persuades us that this new path of action is desirable. Aristotle himself considered the possibility of using persuasion to change the minds of people who have a different conception of what happiness is. And the way to do this is by recurring to particular cases as witnesses and examples of the new ethical generalization we are trying to teach.

In all these matters [about what happiness] (Cf. EE 1217a 21) we must try to

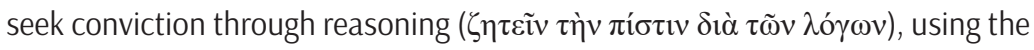
appearances as witness and examples. The best situation is that everyone be in manifest agreement with what we are going to say; failing that, that everyone should in some fashion agree, as they will do when they have had their minds changed. Each person has some affinity with truth, and it is from this that one must prove one's case in these issues in one way or another (EE 1216b 26-32; Inwood's translation with slight modifications).

Throughout these three critiques I have tried to defend the following arguments: (i) that Aristotle allows reason to play a wide specificatory role that includes the specification of the content of the most general goal, establishing what constitutes a happy life; (ii) that our process of habituation involves the training of our rational critical faculties and in consequence our habitual phantasiai of the good are not merely non-rational cognitions; (iii) that reason can establish opinions contrary to habitual phantasiai and, in this way, rational desires opposed to our habitual desires.

\section{Bermúdez' indirect intellectualism}

Bermúdez (2017) embraces the division of labor thesis, but at the same time he realizes that there is other textual evidence that establishes a thesis not coherent with the idea 
that ends are established only through a non-rational cognition of the good. These passages concur to defend the following thesis:

The Priority of Reason: The human soul's rational part must guide the non-rational part, and the non-rational part must in turn listen to reason. Reason should prescribe, character should follow (Bermúdez, 2017, p. 56).

If reason cannot entail the ends of our actions, because they are established through non-rational phantasiai of the good, how is it possible that reason rules over the appetitive part of the soul, as Aristotle intends? Bermúdez' proposal tries to harmonize both types of textual evidence, creating an interpretation in which reason can rule over the appetitive part while at the same time being unable to establish our appetites directly. That is what he calls indirect intellectualism. I will sum up his proposal in three theses: (i) reason cannot directly establish the goals of our actions; (ii) character determines the goals we pursue, by establishing which objects appear pleasant and pursuable and which appear painful and avoidable; and (iii) "reason could determine the phantasia of the good indirectly, by directing habituation toward developing certain character dispositions" (Bermúdez, 2016, pp. 97-98).

Bermúdez' proposal is based upon what he calls the circular structure of human agency. He explains this structure along the following lines and by means of the corresponding figure:

repeated actions generate dispositions of character; character in turn determines practical cognition (i.e. the phantasia of the good); practical cognition activates desires toward the objects that appear good; and desire -mediated by reason's specificatory, instrumental, and coordinating activities- shapes subsequent actions. These actions, in turn, generate dispositions of character. And so on (Bermúdez, 2016, p. 98).

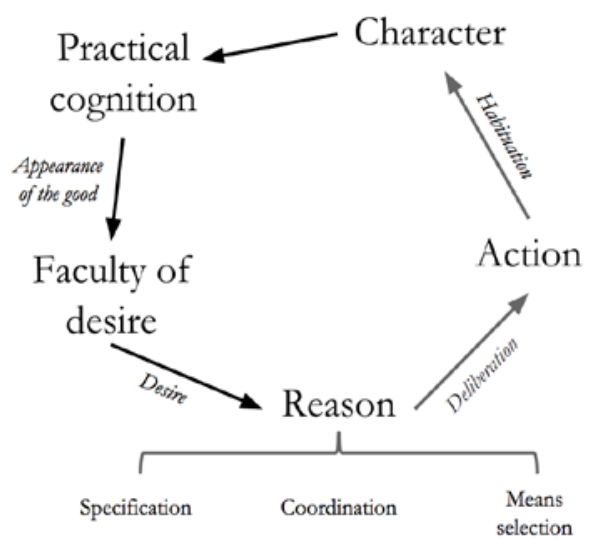

The circular structure of human agency

(Bermúdez, 2016, p. 99) 
Reflecting on this circular structure, Bermúdez finds an important way in which reason can establish the goals of our actions: "by making the whole system bite its tail" (Bermúdez, 2016, p. 99). If reason can control our processes of habituation it can in the long run modify our character, which implies that it can modify our practical cognitions: it can transform our phantasiai of the good, which means, it can change the object of desire and the desire itself. In that way reason indirectly rules over the appetitive part of the soul.

Bermúdez explains that in order to be able to control our processes of habituation, reason should understand each action as practice toward the desired character. Reason can implement its instrumental, specificatory and coordinating functions in order to organize a plan of habituation that leads the agent toward the desired character. And this presupposes that the agent has already laid down as a goal the acquisition of a particular character. Bermúdez says

the originary appearance of a certain character as good must necessarily precede all reasoning and deliberation about habit care. The first phantasia of the good is a consequence of the first steps of an individual's habituation. And importantly, such steps did not depend on her, but were performed by those other people who cared for her (2016, p. 100).

So, it is the task of parents and educators to establish what character we want to build for ourselves.

\section{Critique of indirect intellectualism}

But here is where my problems with indirect intellectualism begin. If we are going to take action as practice, "as a chance for developing the character dispositions that will eventually give our desires the shape that we want them to have" (Bermúdez, forthcoming), this has to do with the fact that neither our character nor our desires have the shape we want them to have, and consequently we want to modify them. But I can only picture two different kinds of modifications we might want to produce: (i) we can agree with the path of habituation that our parents have begun, in so far as we consider the character they expect us to obtain to be desirable. But we may think that we have not yet acquired the desired character, and that we have to continue practicing in order to achieve it. For example, we could think that we should be braver, and that facing dangerous situations in the appropriate way will help us to improve our character and give our particular desires the shape we want them to have.

There is a second type of modification that I can picture: (ii) we might believe that the character our parents and educators were trying to achieve is not really good. For example, I may realize that they have wrongly spoiled me and that I have become 
a self-centered person, whose habitual desires are focused on self-satisfaction. But I may consider - e.g. given the advice of a new friend or the confrontation with different ways of life- that it is much more desirable to be unselfish. I may then conceive my own actions as practice toward the contrary character. That implies that I have to perform many particular actions contrary to my character in such a way that in the long term I can modify my character in the desired way and achieve more altruistic desires.

Bermúdez would not agree with the idea that the agent might conceive the existence of a desired character contrary to the one that appears as good given his habitual dispositions. He insists that the appearance of a character as good is a consequence of the first steps of an individual's habituation, not something he can achieve through any kind of reasoning. However, Aristotle claims that "men do many things against habituation and nature because of reason, if it persuades them that there is a better way of acting" (Pol. 1332b 6-8). Now, an agent could persuade himself to act against his habituation based upon a personal reasoning about his own behavior given the experience of a new shocking situation, as I have argued in my third critique against anti-intellectualism.

But the agent's reason could also furnish non-habitual phantasiai of the good, when he is persuaded by other agents. In many passages Aristotle talks about the importance of persuasion in order to lead people to live different lives, that is, in order to lead them to believe that there is a better way to live, different from what appears to them as good given their habituation. ${ }^{9}$ It is important to notice here that to be persuaded is not to be constrained. "Something is forced whenever its cause is external and the agent contributes nothing" (EN 1110b1-3). But in persuasion the influenced agent, in order to be persuaded, must hear and rationally accept as true the reasoning to which he is listening. Thus, in cases of external persuasion, the reason of the persuaded agent must be able to judge as true phantasiai of the good opposed to his habitual phantasiai.

There is a frequently quoted passage in which Aristotle insists on the possibility of changing from one character to the opposite, which implies that the agent establishes

9 Cf. EE 1216b 25-30; EN 1095b 4-13. Aristotle clarifies that "arguments and teachings surely do not prevail on everyone, but the soul of the student needs to have been prepared by habits for enjoying and hating finely, like ground that is to nourish seed. For someone who lives in accord with his feelings would not even listen to an argument turning him away, or comprehend it, and in that state how could he be persuaded to change" (EN 1179b 24-29; Irwin's translation). Clearly, if we want to persuade someone to change it is because we consider that this person can change his mind, conceiving that the actions that he is currently carrying out are less desirable than those proposed through persuasion. That implies that through reasoning we can modify their phantasia of the good. Aristotle clarifies that this is only possible for someone who has been prepared by habits for enjoying and hating finely, not for someone who lives according to his feelings. What I understand that this clarification means is not that the agent already has the phantasia of the proposed behavior as good (that is what we are trying to provide through persuasion), but that he has been habituated to enjoy what reason establishes as good, desirable and pursuable and, in consequence, that he is able to live according to his reason. 
as desirable a character opposite to the one that he has already acquired through his previous habituation: ${ }^{10}$

and it is possible to become bad instead of good or good instead of bad. (For the bad man, if led into better ways of living and thinking, would progress, if only a little, towards being better. And if he once made even a little progress it is clear that he might either change completely or make really great progress. For however slight the progress he made to begin with, he becomes ever more easily changed towards virtue, so that he is likely to make still more progress; and when this keeps happening it brings it over completely into the contrary state, provided time permits) (Cat. 13a 22-31; Ackrill's translation).

If we focus on the mechanism that allows the two kinds of character transformation that I have pointed out, we are going to realize that it implies direct intellectualism. In both cases it presupposes that we perform actions that do not accord with our characters, pursuing goals different from those established by our characters. In the first case, in order to become braver, I might rationally plan to execute slightly braver actions each day. Let us say, I will stand firm in this frightening situation not the habitual ten minutes, but eleven minutes this week, twelve minutes next week and so on; I'm going to stand firm not only in front of those opponents that look weak, but in front of some that look a little stronger this week, much stronger the next week, and so on. of course, my habitual disposition at this very moment generates the strong habitual desire to run away after ten minutes or in front of stronger opponents, but I have to resist this desire because I want something else, I want to stand firm eleven minutes or in front of this stronger person. This second desire is not the one established by our habitual dispositions: rather, it is contrary to the desire established by them. This is a desire that I produce in accordance with my rational plan to improve my character. I would say that this is a desire established by reason, an Aristotelian $\beta$ ov́ $\lambda \eta \sigma ı s$.

This is much more noticeable in the second type of character transformation. In this case we have to perform particular actions contrary to our characters, which implies that at the very moment of the particular action, our habitual dispositions generate the selfish desire to satisfy ourselves, while at the same time, we do not want to follow

10 Unless, of course, Aristotle is thinking of an involuntary change of character, which does not imply that the agent conceives having a different character as desirable. Ramos-Umaña, following Bondenson, has pointed out that when Aristotle explains how character

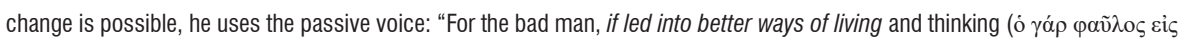

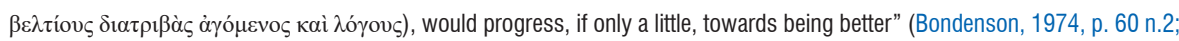
Ramos-Umaña, 2012, pp. 97-98). However, it is important to keep in mind that $\alpha \gamma$ ó $\mu \varepsilon v o \varsigma$ could also be a middle voice, which leaves open the possibility of an autonomous and voluntary change of character. On the other hand, when Aristotle explains the way we can improve our character through habituation, he explicitly says this is a task we have to carry out on our own: "we shall come to know our own tendencies from the pleasure and pain that arise in us. We must draw ourselves off in the contrary

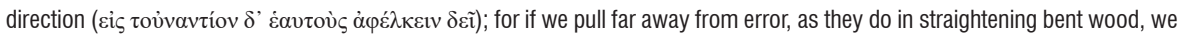
shall reach the intermediate condition" (EN 1109b 2-7; Irwin's translation). 
this desire: instead, we want to perform the altruistic action. This presupposes that we establish a desire contrary to our habitual desire, which implies that we create a phantasia of an altruistic action as good, contrary to our selfish habitual phantasia.

The process of character transformation implies that reason has the power to create phantasiai of the good different from the phantasiai established by our habitual dispositions, which lead to desires different from our habitual desires and actions different from our habitual actions. These actions are those that Bermúdez understands as practice to modify our characters and "eventually give our desires the shape that we want them to have", but this presupposes that we can directly establish the particular goal of each action included in the plan of character transformation. In the long term, this will modify our habitual phantasiai, desires and actions, but this is only possible if, in the short term, reason can directly establish phantasiai, desires and actions contrary to or slightly different from the character we want to modify. If we preclude this possibility, we will only be able to have desires in correspondence with our already established character, and thus, will only be able to perform the same kind of action that we already perform. Through this procedure the circular structure of human agency will only reinforce the already established character, just as walking around and around in circles will only make the path clearer and deeper. Something has to allow a slight deviation from the path, and this something is reasoning from new experiences.

\section{An alternative interpretation}

In the previous sections I have argued that, despite anti-intellectualist efforts, reason can play the role of directly establishing the phantasiai of the good and thus molding our desires. In doing this, I am clearly embracing the Priority of reason thesis. But what about the well-documented Division of labor thesis? Was asserting that character is in charge of establishing ends, while reason has the task of finding things that contribute to achieving the goal, simply an unfortunate oversight on Aristotle's part? Is he contradicting himself? I do not think so. I believe that the apparent tension we can find between the two theses disappears if we remember that Ethics is not the field of what happens always in the same way. Instead, what happens in the human realm can vary according to circumstances. Therefore, explanation in the field of human praxis is not universal and necessary, but always related to the particular context. And I think this is the clue here: the psychological phenomena that happen in the human mind when people are acting according to their character are very different from the psychological process that happens when someone is trying to perform an action contrary to his or her character. In the first case, it is essential to maintain that character is establishing the goal of human actions, while reason is merely looking for what will contribute to achieving the goal. In the second case, it is essential to remember that reason has a priority in the human soul inasmuch as it can determine renovated phantasiai of the 
good, rational desires and actions contrary to our character. Given that Aristotle has both problems in mind in his ethical studies, he needs to defend both theses. But of course, given that each thesis is related to a different psychological explanation, there is no real tension between them.

In order to clarify this, allow me to ask, why should we care about our character, if reason is able to establish our phantasiai, desires and actions directly? Why should we trouble to embrace a long-term plan of character formation and transformation? The reason is that each character is inherently linked with its corresponding phantasia and action, which means that this character allows us to immediately visualize the corresponding kind of action as good and, at the same time, allows us to perform the corresponding action much more easily. But if we have not yet acquired this character, our reason will have to fight strongly against our habitual dispositions, generating alternative phantasiai of the good and stimulating us to perform actions that are difficult for us to perform. So, the reason that we want to modify our character is that we want this kind of representation and action to become much more natural in the future for us. Once we have acquired the desired habitual dispositions, the desires we want to have and the actions we want to perform (that we already have and perform as part of our rational plan of character transformation) will become our habitual desires and our habitual actions.

Once we have the character we want to have, we can rely on letting ourselves simply follow the desires that character establishes for our actions. Under these circumstances, we can rely on the desired division of labor that Aristotle defends in many passages: character will establish our desires while reason will find what contributes to achieving the goal. But in cases in which doubts arise about the desirability of our habitual dispositions, representations and actions, we should not rely on this division of labor. In these cases, we must rely on the priority of reason, giving to reason the function of establishing different phantasiai of the good and thus molding different desires that lead us to different actions and, in the long run, to acquire different characters.

It is important to notice that this proposal modifies Bermúdez' circular conception of human action. According to Bermúdez, (i) character determines practical cognition (i.e. the phantasia of something as good), (ii) practical cognition activates the faculty of desire, producing a desire toward the objects that appear good, and (iii) desire -mediated by reason's specificatory, instrumental, and coordinating activities- produces subsequent actions (Bermúdez, 2016). Instead of this conception I propose the following process: (i) character is not the only source that can establish practical cognition. As I have argued throughout this paper, reason can also furnish non-habitual cognitions of the end. (ii)

Practical cognition activates the faculty of desire, producing a desire toward the objects that appear good. And since the sources of practical cognition are multiple, there could also be a conflict between different desires (de An. 433b 5-10). Given that it is impossible for opposite desires to be simultaneously effective, that is, it is 
impossible for an animal to move simultaneously in opposite directions, Aristotle says that what will lead human beings to action is what is predominantly desired

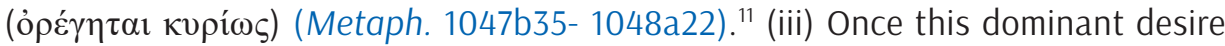
is established, the instrumental role of reason determines what actions should be performed and, when there is no hindrance, the action is immediately and necessarily carried out.

\section{References}

Aristotle. (1884). Aristotelis ethica eudemia. F. Susemihl, (Ed.). Teubner.

Aristotle. (1924). Aristotle's metaphysics. 2 vols. W. D. Ross (Ed.). Oxford University Press. https://doi.org/10.1093/actrade/9780198847779.book.1

Aristotle. (1961). Aristotle. De anima. W. D. Ross (Ed.). Clarendon Press. https://doi.org/10.1093/ actrade/9780198141556.book.1

Aristotle. (1963a). Aristotle: politics. W. D. Ross (Ed.). Oxford University Press.

Aristotle. (1963b). Aristotle's categories and De interpretatione (J. L. Ackrill, Trans.). Clarendon Press.

Aristotle. (1984a). Politics. In J. Barnes (Ed.), The complete works of Aristotle (B. Jowett, Trans.). Oxford University Press.

Aristotle. (1984b). On the soul. In J. Barnes (Ed.), The complete works of Aristotle (J. A. Smith, Trans.). Oxford University Press.

Aristotle. (1984C). Aristotelis ethica nicomachea. I. Bywater (Ed.). Clarendon Press.

Aristotle. (1985). Aristotle's the motu animalium. (M. Nussbaum, Trans.). Princeton University Press.

Aristotle. (1999). Nicomachean ethics (second edition) (T. Irwin, Trans.). Hackett. https://doi. org/10.1093/oseo/instance.00258595

Aristotle. (2013). Aristotle eudemian ethics (B. Inwood \& R. Woolf, Trans.). Cambridge University Press.

Bermúdez, J. P. (2016). Practical reason, habit, and care in Aristotle. Praxis Filosófica, 43, 77-102. https://doi.org/10.25100/pfilosofica.v0i43.3156

Bermúdez, J. P. (2017). Can reason establish the goals of action? Assessing interpretations of Aristotle's theory of agency. Discusiones Filosóficas, 18(30), 35-62.

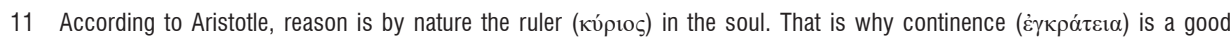
disposition of the soul, whereas incontinence ( $\dot{\alpha} \kappa \rho \alpha \sigma i \alpha)$ is a bad disposition. A continent person will be able to hear and follow the dictates of reason, since his rational desire will be the dominant desire. The incontinent person will periodically have as a dominant desire a desire opposite to the one established by reason. 
Bermúdez, J. P. (forthcoming). The politics of care: how reason shapes character in Aristotle's polis.

Bondenson, W. (1974). Aristotle on responsibility for one's character and the possibility of character change. Phronesis, 19(1), 59-65. https://doi.org/10.1163/156852874X00086

Broadie, S. (1991). Ethics with Aristotle. Oxford University Press.

Grönroos, G. (2015). Wish, motivation and the human good in Aristotle. Phronesis, 60 (1), 60-87. https://doi.org/10.1163/15685284-12341279

Irwin, T. H. (1975). Aristotle on reason, desire, and virtue. The Journal of Philosophy, 72(17), 567-578. https://doi.org/10.2307/2025069

McDowell, J. (1998). Some issues in Aristotle's moral psychology. In Mind, value, and reality (pp. 23-49). Harvard University Press. https://doi.org/10.1017/CBO9781139166348.005

Moss, J. (2012). Aristotle on the apparent good: perception, phantasia, thought, and desire. Oxford University Press. https://doi.org/10.1093/acprof:0so/9780199656349.001.0001

Price, A. W. (2011). Aristotle on the ends of deliberation. In M. Pakalauk \& G. Pearson (Eds.), Moral psychology and human action in Aristotle (pp. 135-158). Oxford University Press. https://doi.org/10.1093/acprof:0so/9780199546541.003.0007

Ramos-Umaña, L. (2012). Sobre la formación del carácter en Aristóteles. (Tesis de maestría). Universidad Nacional Autónoma de México.

Vigo, A. (2001). Verdad práctica y virtudes intelectuales según Aristóteles. Philosophica, 24-25, 365-407.

Vigo, A. (2012) Deliberación y decisión según Aristóteles. Tópicos, Revista de Filosofía, 43, 51-92. https://doi.org/10.21555/top.v0i43.32

Wiggins, D. (1975). Deliberation and practical reason. Proceedings of the Aristotelian Society, 76, 29-51. https://doi.org/10.1093/aristotelian/76.1.29 